\title{
Interventions in the Subsoil in the Netherlands
}

\section{-Tension between Central Planning and Local Acceptance}

\author{
Geert Roovers ${ }^{1}$, Michael Duijn² \\ ${ }^{1}$ Applied Science on Soil and Subsoil, Saxion University, Deventer, Netherlands \\ ${ }^{2}$ Erasmus University Rotterdam, Rotterdam, Netherlands \\ Email: g.j.roovers@saxion.nl,duijn@essb.eur.nl
}

How to cite this paper: Roovers, G., \& Duijn, M. (2021). Interventions in the Subsoil in the Netherlands. Open Journal of Political Science, 11, 1-11.

https://doi.org/10.4236/ojps.2021.111001

Received: September 12, 2020

Accepted: November 30, 2020

Published: December 3, 2020

Copyright $\odot 2021$ by author(s) and Scientific Research Publishing Inc. This work is licensed under the Creative Commons Attribution International License (CC BY 4.0).

http://creativecommons.org/licenses/by/4.0/

\section{Open Access}

\begin{abstract}
Subsoil interventions in the Netherlands, such as gas and oil extraction, thermal energy extraction or $\mathrm{CO}_{2}$-storage, cause tensions. Planning leads to local resistance, debate and often delay or cancelling of initiatives. The central characteristics of this planning are the main cause. As the transition to sustainable energy asks for more interventions in the subsoil, these tensions get problematic, and hinder the transition. In this article, we investigate this problematic nature of central public planning of subsoil interventions in the Netherlands. We do this by using a network management perspective and local acceptance theory and researching two cases. We conclude that a more prominent role of local actors, using localism and soft power, is crucial. With this article, we want to contribute to national and international discussions about the planning and governance of subsoil initiatives and strengthening of local involvement in these.
\end{abstract}

\section{Keywords}

Subsoil Interventions, Network Management, Local Involvement, Participation

\section{Introduction}

Subsoil interventions in the Netherlands have recently been politicized. This can be seen in fierce turmoil about gas mining and subsequent earthquakes in Groningen, discussions on shale gas, cancelled $\mathrm{CO}_{2}$ storage in Barendrecht and recent controversy between the Ministry and local government over the proposed gas extraction in Smallingerland. All these examples show local protests, postponement or adjustment of initiatives and a lot of media attention (see e.g. Daamen et al., 2010; Paukovic et al., 2011; Metze \& Turnhout, 2014; Van Os, 2018). Following this, subsoil interventions in the Netherlands can be characte- 
rized as "win-lose" situations, where the benefits go to (inter)national private sector initiators and national government, without local stakeholders directly benefiting. The burden of these interventions, such as nuisance and safety risks, often affects the immediate residents (see e.g. Tweede Kamer, 2015, Algemene Rekenkamer, 2020). This is all the more problematic, because the desired transition to sustainable energy in the Netherlands requires many new interventions in the subsoil, such as the extraction of geothermal energy and the storage of sustainable energy. This raises the question what the main reasons for these tensions are and how governments within the Dutch mining planning process can anticipate on them. In this article, we investigate these questions. We do this by examining two cases from the perspectives of network management and local acceptance.

\section{Subsoil Interventions from the Perspectives of Network Management and Local Acceptance}

An intervention in the subsoil involves extracting substances from the subsoil or storing substances in it. Such interventions often consist of drilling tubes into the subsoil, from hundreds of meters up to several kilometers into the depth, and subsequent infrastructure for transporting these substances to plants elsewhere to process them. The drilling can cause local earthquakes, land subsidence, spilling and other safety and environmental risks. Subsoil interventions in the Netherlands are therefore prone to strict safety and environmental rules and legislation. Subsoil interventions involve various stakeholders (mining companies, licensees (government), provinces, municipalities, residents and action groups). In the Netherlands planning on subsoil interventions is covered by the Mining Act. First, informal planning takes place within the limited circle of initiator (mining company) and national government, supported by national knowledge institutes. Then there is a formal procedure on granting a permit. In this procedure, local governments only have an advisory role. Local participation on subsoil initiatives thus is limited to information and advice at the (formal) end of the planning. Furthermore, some stakeholders involved in mining initiatives consider local participation to be disadvantageous (Van Os, 2018). They consider ignorance of local parties as the main obstacle to decision-making and see adequate informing of the local actors as the only solution. The planning on interventions in the subsoil in the Netherlands can therefore be characterized by a "centrally planned" process, targeted at single issue decision-making (Zima \& Vriezen, 2011; De Vries et al., 2013; Van Dunné, 2014).

Such centrally driven planning can create problems. For example, Rotmans et al. (2005) argues that central control is increasingly failing to provide guidance in a more and more complex society, by referring to authors as Hooghe and Marks (2001), March and Olson (1995), Pierre (2000) and Scharpf (1999). De Bruijn et al., 2002; De Bruijn \& ten Heuvelhof, 2007, argue that in a network of mutually dependent actors central control has little chance of success. A forms planning that is deemed more appropriate is network management, based on 
extensive interactions between actors involved (Castells, 1996; Dirven, Rotmans, \& Verkaik 2002; De Bruijn et al., 2002; De Bruijn \& ten Heuvelhof, 2007). Early participation of stakeholders and an open and secure process play an important role in this. Such an approach requires multi-goal and multi-interest processes. In such an approach it must be possible "to achieve something" for everyone, following a mutual gain approach (Susskind \& Field, 1996) or productively manage their network (Koppejan \& Klijn, 2004; De Bruijn \& ten Heuvelhof, 2007).

Subsoil interventions take place locally, on the site where a bore enters the ground to extract salt, gas or heat, or to enable subsoil storage. Many authors indicate that local support is crucial in continuing subsoil initiatives (Van Os, 2018; Ter Mors, 2009; Daamen et al., 2010). For example, Van Os (2018) argues that the challenge to allow local stakeholders to participate properly proves to be the most important obstacle in planning processes on subsoil storage of $\mathrm{CO}_{2}$ in the Netherland. This brings subsoil interventions into the domain of local acceptance. Wüstenhagen et al. (2007) state that acceptance by a local community is determined by five factors, following research into the local acceptance of wind energy initiatives: community attitudes towards (often new) technology, proximity to the intervention, perceived honesty and openness of the decision-making process, visual impact on the landscape, and the image of the initiator by the local community. Paukovic et al. (2011) found that the biggest obstacle for the storage of $\mathrm{CO}_{2}$ in the Netherland was the perceived safety of the initiative. Research also shows that local residents often have more confidence in their local municipality than in the national government (Daamen et al., 2010). Thus, the role of local governments in the centrally driven planning of subsoil interventions is crucial. Given the central characteristics of planning on subsoil issues, this leads to a high risk of problems with local acceptance. Local governments may play a bridging role between the planning process governed by the national government and (inter)national private sector firms and the acceptance of the outcomes of this planning process by the local community.

\section{Two Cases with Subsoil Interventions}

From this theoretical perspective, we can conclude that for successful interventions in the subsoil, especially the realization of local support, local acceptance of the intervention is crucial. In this the following aspects play an important role:

- Method of planning: central control versus network management;

- Acceptance of the intervention by the local community, in particular determined by

o community attitude towards technology used and the initiator(s);

o experienced honesty and openness of the process.

- Role of the local government.

We researched these aspects in two cases in the Netherlands, namely the initiatives to store $\mathrm{CO}_{2}$ in the subsoil at Barendrecht and the extraction of salt in Enschede. These are two cases in which there is local resistance, leading to the can- 
cellation of the subsoil procedure (Barendrecht) and renewed debate about the subsoil intervention (Enschede). The main research strategy was the multiple case study research (Eisenhardt, 1989; Stake, 2013) with two representative cases to provide an in-depth understanding of the phenomena. The data analysis was based on a qualitative case-study approach, described by Yin (2003). The data collection for these case studies was organized through triangulation (Patton, 1987; Tellis, 1997), using document analysis, 15 in-depth interviews with stakeholders from different perspectives and participatory observation of policy meetings.

\section{$\mathrm{CO}_{2}$-storage at Barendrecht ${ }^{1}$}

In 2007, the Ministry of Economic Affairs launched a tender for large-scale delivery and storage of $\mathrm{CO}_{2}$ in the subsoil, as well as its monitoring. The tender followed the coalition agreement of Cabinet Balkenende IV and European policy on reducing $\mathrm{CO}_{2}$-emissions. Storing $\mathrm{CO}_{2}$ in the deep subsurface can prevent climate change due to rising $\mathrm{CO}_{2}$ concentrations. Empty gas fields are attractive locations for the storage of $\mathrm{CO}_{2}$ because there often still is infrastructure and the geology of these reservoirs is known in detail due to previous gas extraction.

The tender led to a contract to a consortium of mining companies to store at least 0.2 megatons of $\mathrm{CO}_{2}$ per year in empty gas reservoirs underneath Barendrecht. This location had been identified by the consortium as the most suitable location. In their analysis, a trade-off was made between storage in the North or the West of the Netherlands. In the north there were no sources that provide sufficient (chemically) pure $\mathrm{CO}_{2}$ for the project. The consortium will then investigate into 16 sites in the Western Netherlands, of which the De Lier gas field and the Barendrecht gas field remained. Barendrecht is ultimately chosen because it best meets the required preconditions.

The consortium started preparations in 2008 . They informed the municipality of Barendrecht, started procedures and organized information hearings for the residents. A storm of local protest emerged, particularly targeted at the safety and security risks of the storage. The municipality and the Ministry set up consulted structures, and the Ministry changed and intensified its communication. An intense controversy resulted, in the formal consultation structures and in the media, about the (un)certainties and the (un)desirability of the storage. This first created resistance among local residents and the city council. This put pressure on the support for decision-making at the National level. Finally, in 2010, the Minister of Economic Affairs cancelled the project "because of the lack of support" among the local population.

\section{Salt mining in the municipality of Enschede ${ }^{2}$}

In the region of Enschede, salt has been extracted from the subsoil since 1919. Recently, incidents occurred. This started in mid-2008, resulting in several leaks in transportation pipes. These caused local political uproar and disrupted relations between the mining company and the municipality of Enschede. In addition to salt extraction, the debate also went about exploiting empty salt caverns

${ }^{2}$ Based on Duijn, M., A. Janssen, A.W. van Buuren (2018), Gemeente Enschede (2018). 
for subsoil storage of gas oil, wastewater injections into empty gas fields and stabilization of old, abandoned salt caverns.

The rapid succession of incidents in the relatively small region first led to attention from the media and the municipality of Enschede. They mobilized provincial and national politicians. This attention was partly fueled by the initially incomplete and untimely communication by the mining company. Until the end of 2016, the mining company seemed to have little understanding of the mechanism that the abovementioned incidents would lead to social and political anxiety. The unrest and with it the disturbed relations between local actors on the one hand and the mining company and the Ministry of Economic Affairs on the other-reached a peak in 2016. In 2017, following the incidents, the city council set up a committee to advise on how the municipality could "take control of its own subsoil". In 2017, several attempts were made to restore trust between the involved actors. The actors need to discover how they can organize their interactions in a confidence-building way.

\section{Analysis of the Cases}

The previous paragraph described two cases of subsoil intervention. In this section we analyze the cases on the basis of the aspects outlined in the theoretical perspective.

\begin{tabular}{|c|c|c|}
\hline Aspect & Barendrecht & Enschede \\
\hline \multirow{5}{*}{$\begin{array}{l}\text { Method of planning: central } \\
\text { control vs network management; }\end{array}$} & $\begin{array}{l}\text { Central control, single-issue and information: based on } \\
\text { tender form the national government and subsequent } \\
\text { support for the "awarded" mining company. }\end{array}$ & $\begin{array}{l}\text { Central control, single issue and information, on the } \\
\text { basis of the mining law and the supervision of the } \\
\text { permits granted to mining company. }\end{array}$ \\
\hline & $\begin{array}{l}\text { Local participation after the tender stage was organized } \\
\text { after the mining company has determined the specific } \\
\text { location. There is no room for win-win } \\
\text { anymore. }\end{array}$ & $\begin{array}{l}\text { Informing the local government takes place only after } \\
\text { leaks in the media. Mining company first informs } \\
\text { national government (as supervisor) and only later on } \\
\text { the local government. In later phases, direct } \\
\text { communication with the municipality takes place. } \\
\text { There is no room for win-win. }\end{array}$ \\
\hline & National government is initiator, supported by national & \\
\hline & $\begin{array}{l}\text { knowledge institutes for mining. In the next stage the } \\
\text { most important interaction takes place between mining } \\
\text { company and the local government. National } \\
\text { government remained in the background but will have } \\
\text { to step up later if decision-making stagnates and local } \\
\text { resistance becomes massive. Local government and } \\
\text { community are initially reactive, but then become } \\
\text { proactive. }\end{array}$ & $\begin{array}{l}\text { Initial interaction is between mining company and } \\
\text { national government and national knowledge institutes } \\
\text { for mining. Subsequently, the most important } \\
\text { interaction between the mining company and the } \\
\text { municipality is created. Local community puts local } \\
\text { politics in place and in doing so the local government. } \\
\text { National government is more in background. }\end{array}$ \\
\hline & $\begin{array}{l}\text { There is no open process at the start, no interaction. } \\
\text { Subsequently, polarization takes place. Learning from } \\
\text { each other does not occur as a result. }\end{array}$ & $\begin{array}{l}\text { There is no open process at the start, no interaction. } \\
\text { Subsequently, polarization takes place. This leads to } \\
\text { interaction that creates the beginning of learning. }\end{array}$ \\
\hline \multirow{4}{*}{$\begin{array}{l}\text { Local acceptance: } \\
\text { Attitude to initiator and } \\
\text { technique } \\
\text { Experienced openness and } \\
\text { honesty }\end{array}$} & Mining company is distrusted after tender, choice & Mining company is distrusted after incidents and poor \\
\hline & location and poor communication. & communication. \\
\hline & Technique CCS is distrusted. Uncertainties, examples & The method of maintenance and drilling of the mining \\
\hline & from abroad used to substantiate this. & company is called into question. \\
\hline
\end{tabular}




\section{Continued}

Local government is reactive at first, and not involved. After local uproar and questions in the city council, the

Role local government local government developed visibility and obstructive force, by teaming up with the regional government,

claiming a position as active opponent of the initiative.
Local government is reactive first. After a fuss and media reports, the local government becomes active and starts a conversation with those involved. The municipality is also developing a strategy to "take control on its own subsoil", based on claiming a more prominent role in the relevant policy network.

Both cases have a similar pattern of planning and subsequent outcomes. The centrally oriented planning is followed by local turmoil when information and incidents are picked by local governments and politicians. The resulting turmoil increases distrust and sparks activation of the local community. We can discern three groups of actors with similar interests and perspectives: 1) national government and their advisors of knowledge institutes, 2) private sector mining companies and operators and 3) the local community (residents, local governments and local NGO's). In both cases we see that central planning by the national government (the Ministry of Economic Affairs) and the (inter)national mining companies is initially dominant. This leads to resistance and delay, and in Barendrecht even to the cancellation of the initiative. It can also be seen that in both cases local governments act passively and merely react to incidents or unfavorable information about local impacts of the intended subsoil intervention. Only when resistance from local residents and organizations and city councils arises, action and interaction with the national government and mining companies unfolds. In Barendrecht this leads to polarization and cancellation of the initiative. In Twente, this first leads to polarization, but then to the start of a dialogue between actors at the national and local level.

Social acceptance of the interventions is absent (Barendrecht) or under pressure (Enschede). The municipality can thwart the initiative, especially in Barendrecht, supported by the local community. There is:

- Little to no room for issues of the local community: it is a single-issue, single interest initiative.

- Participation is limited to informing the local community. This is done at the moment when first stages of the centrally oriented planning process for the intervention are already done by the mining company and the national government. Peculiarly enough, the subsequent uproar over the decisions, through residents, local media and the city council, in fact creates interaction between the local government and the mining company, as an important part of local participation.

- The process is considered non-transparent and unfair by the local community in both cases. The first stages of the planning process are perceived as non-inclusive and covertly by the local government and local community.

- In both cases, the attitude of the local community towards the initiator (the mining company) and the technology used, is becoming unfavorable. In Twente, the attitude is ambivalent, because the mining company has long been rooted in the region and provides employment and contributes to the 
local society. In Barendrecht, gas extraction was executed in the past, leaving an empty gas field as promising location for $\mathrm{CO}_{2}$-storage. Although one might expected that the local community was used to subsoil interventions, the centrally oriented planning process for $\mathrm{CO}_{2}$-storage created its own resistance.

In both cases, the combination of a centrally planned decision-making, single-issue and single interest approach and late and limited participation leads to local resistance. This local resistance creates a reserved, and sometimes even negative, attitude of the local community towards the mining company and national government. Local acceptance of the subsoil intervention is therefore problematic in both cases, based on the following observations. First there is no formal role in decision-making for the local government and other local parties, such as residents. Second, the national government acts solely on the National Mining Act and stands at a great distance from the local situation. The Ministry only shifts into gear when tension and local resistance come into focus. However, a prominent difference can be observed between the two cases as well. Where ongoing hostility in Barendrecht can be observed, leading to cancelling the initiative, the Twente case finally follows a different road. From the hostility the first seeds of a dialogue can be seen, with the local government using network and communication strategies ("soft power") to start taking control on planning of their own subsoil.

\section{Discussion}

In the cases we see that local governments do not have a formal role nor instruments to influence the planning in a more favorable direction that acknowledges the interests of the local community. As such local governments need to develop and deploy so-called soft power instruments (Nye, 2008; Jordan, Wurzel, \& Zito, 2005). "Soft power" is often implemented in diplomatic affairs, next to the policy domains in which influencing human behavior is one of the most important instruments, such as environmental or safety policy. Nye (2008) defines "soft power" the ability to affect others to obtain the outcomes one wants through attraction, rather than coercion or payment. In terms of policy instruments "soft power" concerns activities that "produce" conviction or seduction (Nye, 2008). In the described cases local governments are deployed to influence the planning and decision-making in a way that represents and defends the interests of the local community more prominently. Soft power can also be deployed to mobilize and unite the local network of actors to influence the planning process of the intended subsoil intervention.

Next to influencing the planning, it is worthwhile to reflect on the question how local interests, concerns and risks can get a more prominent role in centrally planned subsoil interventions. The idea of localism (Davidson, 2019) perhaps offers some leverage. Davidson (2019: p. 954) defines localism as the discourse of local legal power and state-local relations. Decentralization of formal responsi- 
bilities to the local level has some advantage. First it enhances democratic participation and political involvement (see: Mansfield \& Winthrop, 2000). Second at the local there is more room for experimentation with policy (cf. Frug, 1999) because local policy experiments enable quicker and better learning than at higher levels of scale where feedback loops are more complex and indirect. Third, local governments are capable of acting as counterweight for power concentration at national level, by critically commenting on intended new policies (based on Bulman-Pozen \& Gerken, 2008). However, Briffault (2018) points to negative effects of local government empowerment: "[L]ocalism reflects territorial economic and social inequalities and reinforces them with political power". Davidson refers to this as parochialism that may seriously damage the quality of decision-making because only well-established, private interests might be represented in local policies, at the expense of parts of the local community that are incapable of representing their interests. However, it can be questioned if parochialism will lead to this negative effect in subsoil interventions because these are highly dominated by centrally planned, (inter)national interests. More attention to public and private interests at the local level will put the balance straight.

Discussing the two cases, it can be acknowledged that the more prominent use of soft power by local governments and the incorporation of localism in the planning process of subsoil interventions, may put local communities in a better position to represent their interests in the centrally planned processes for (inter)national mining and storage projects.

\section{Conclusion}

Interventions in the subsoil in the Netherlands are becoming increasingly important, especially in the light of the transition to sustainable energy. However, with the current National Mining Act institutions, these interventions are sensitive to local problems with decision-making and the degree of local acceptance. This research shows that the decision-making of interventions in the subsoil is characterized by centrally planned and a single-issue, single interest approach. Local governments and communities are only involved when the location of the operation has already been determined by mining companies and the national government. The cases confirm that this leads to substantial local resistance and problematic planning and decision-making. Furthermore, through substantial resistance by local residents and the city council, the decision-making process is corrected, with delay and/or significant adjustment as outcomes, and local governments "earn" an informal but influential position in decision-making. Finally, the role of the local government in decision-making in the cases is crucial, but 1) they are not included by the national government and (inter)national mining companies in the first stages of the planning process of the initiative, and 2) they don't take their role on their own. The local governments tend to be reactive to the centrally planned interventions and only seem to shift into gear when local 
resistance arises, often fueled by concerns of local residents and/or questions raised by the city council.

\section{Conflicts of Interest}

The authors declare no conflicts of interest regarding the publication of this paper.

\section{References}

Briffault, R. (2018). The Challenge of the New Preemption. Stanford Law Review, 70, 1995.

Bulman-Pozen, J., \& Gerken, H. K. (2008). Uncooperative Federalism. Yale Law Journal, $118,1258-1307$

https://scholarship.law.columbia.edu/faculty_scholarship/1545

Castells, M. (1996). The Information Age: Economy, Society and Culture, Vol. I. The Rise of the Network Society. Malden, MA: Blackwell Publishers.

Daamen, D., Terwel, B., \& ter Mors, E. (2010). Wat weten en vinden Barendrechters van het $\mathrm{CO}_{2}$ opslag plan en van de voorlichting en besluitvorming over dit plan? Resultaten van een enquête in mei 2010 onder ruim 800 inwoners. Leiden. (In Dutch)

Davidson, N. M. (2019). The Dilemma of Localism in an Era of Polarization. Yale Law Journal, 128, 954-1001.

De Bruijn, H., \& ten Heuvelhof, E. (2007). Management in netwerken: Over veranderen in een multi-actorcontext (2nd Revised ed.). (In Dutch)

De Bruijn, H., ten Heuvelhof, E., \& in't Veld, R. (2002). Procesmanagement, over procesontwerp en besluitvorming (2nd Revised ed.). (In Dutch)

De Vries, A., van Est, R., \& van Waes, A. (2013). Samen winnen. Verbreding van schaliegasdiscussie en handvatten voor besluitvorming. Den Haag: Rathenau Instituut. (In Dutch)

Dirven, J., Rotmans, J., \& Verkaik, A. P. (2002). Samenleving in Transitie: Een vernieuwend gezichtspunt; Ministerie LNV, Den Haag, ICIS, Maastricht, Innovatie Netwerk Groene Ruimte en Agrocluster, Den Haag. (In Dutch)

Eisenhardt, K. M. (1989). Building Theories from Case Study Research. Academy of Management Review, 14, 532-550. https://doi.org/10.5465/amr.1989.4308385

Frug, G. E. (1999). City Making: Building Communities without Walls. Princeton, NJ: Princeton University Press.

Hooghe, L., \& Marks, G. (2001). Multi-Level Governance and European Integration. Oxford: Rowman \& Littlefield Publishers Inc.

Jordan, A., Wurzel, R. K. W., \& Zito, A. (2005). The Rise of “New” Policy Instruments in Comparative Perspective: Had Governance Eclipsed Government? Political Studies, 53, 477-496. https://doi.org/10.1111/j.1467-9248.2005.00540.x

Kamer, T. (2015). Behandeling Rapport Onderzoeksraad voor Veiligheid over het Gasgebouw. TK 58-20-1. Den Haag.

Koppejan, J., \& Klijn, E.-H. (2004). Managing Uncertainties in Networks. A Network Approach to Problem Solving and Decision Making. London: Routledge.

Mansfield, H. C., \& Winthrop, D. (2000). Alexis de Tocqueville, Democracy in America. Chicago, IL: University of Chicago Press.

March, J. G., \& Olsen, J. P. (1995). Democratic Governance. New York: Free Press. 
Metze, T., \& Turnhout, E. (2014). What the Frack? Politiserende deliberatie in de besluitvorming over schaliegas. Bestuurskunde, 23, 21-30. https://doi.org/10.5553/Bk/092733872014023002003

Nye, J. S. (2008). Public Diplomacy and Soft Power. The Annals of the American Academy, 616, 94-109. https://doi.org/10.1177/0002716207311699

Patton, M. Q. (1987). How to Use Qualitative Methods in Evaluation. Newbury Park, CA: Sage.

Paukovic, M., Brunsting, S., \& de Best-Waldhober, M. (2011). The Dutch General Public's Opinion on CCS and Energy Transition: Development in Awareness, Knowledge, Beliefs and Opinions Related to Information and Media Coverage (pp. 1-189). CATO2-WP5.3-D02a.

Pierre, J. (2000). Debating Governance. Oxford: Oxford University Press.

Rekenkamer, A. (2020). Resultaten verantwoordingsonderzoek 2019 Ministerie van Economische Zaken en Klimaat (XIII) Rapport bij het jaarverslag. Den Haag. (In Dutch)

Rotmans, J., Loorbach, D., \& van der Brugge, R. (2005). Transitiemanagement en duurzame ontwikkeling; Co-evolutionaire sturing in het licht van complexiteit. Beleidswetenschap, 19, 3-23. (In Dutch)

Scharpf, F. W. (1999). Governing in Europe. Effective and Democratic? Oxford: Oxford University Press. https://doi.org/10.1093/acprof:oso/9780198295457.001.0001

Stake, R. (2013). Multiple Case Study Analysis. New York: Guilford.

Susskind, L., \& Field, P. (1996). Dealing with an Angry Public: The Mutual Gains Approach to Resolving Disputes.

Tellis, W. M. (1997). Introduction to Case Study. The Qualitative Report, 3, 1-14. https://doi.org/10.46743/2160-3715/1997.2024

Ter Mors, E. (2009). Dealing with Information about Complex Issues. The Role of Source Perception. Leiden: Kurt Lewin Instituut.

van Dunné, J. M. (2014). Een koperen jubileum van de nieuwe Mijnbouwwet. Tijdschrift Voor Gezondheidsschade Milieuschade en Aansprakelijkheidsrecht, 28, 174-193. (In Dutch) http://hdl.handle.net/1765/101542

van Os, H. (2018). Modular Evaluation Method Subsurface Activities: Analyzing the Spatial Coordination of the Subsurface in the Netherlands from a Social Acceptance Perspective. Groningen: University of Groningen.

Wüstenhagen, R., Wolsink, M., \& Bürer, M. J. (2007). Social Acceptance of Renewable Energy Innovation: An Introduction to the Concept. Energy Policy, 35, 2683-2691. https://doi.org/10.1016/j.enpol.2006.12.001

Yin, R. K. (2003). Case Study Research, Design and Methods (3rd ed.). Applied Social Research Methods Series Vol. 5, London: SAGE Publications.

Zima, L. A., \& Vriezen, G. A. (2011). Amendment of the Mining Act. A Nice Late Summer or a New Spring? Wijziging van de Mijnbouwwet. Mooie nazomer of nieuwe lente? (In Dutch) 


\section{Case $\mathrm{CO}_{2}$-Storage Barendrecht}

Daschveld, C. (2009). Ondergrondse $\mathrm{CO}_{2}$-opslag. Over interactieprocessen en opinievorming met betrekking tot de ondergrondse $\mathrm{CO}_{2}$-opslag in Barendrecht; Afstudeerscriptie, Erasmus Universiteit Rotterdam; Visser \& Smit Hanab; Augustus 2009, Rotterdam/Papendrecht. (In Dutch)

Pauw, M. (2011). $\mathrm{CO}_{2}$-Opslag in Barendrecht als postnormale casus. Masterthesis Universiteit van Utrecht, 3138577. (In Dutch)

Shell $\mathrm{CO}_{2}$ Storage B.V. (2008). MER Ondergrondse opslag van $\mathrm{CO}_{2}$ in Barendrecht, Deelrapport 1: Samenvattend hoofdrapport (overzicht op hoofdlijnen van MER en alle bevindingen); Den Haag. (In Dutch)

Verlinde, M. (2013). $\mathrm{CO}_{2}$-opslag in de Nederlandse ondergrond, Universiteit Utrecht/CATO, In; GEA, maart 2013, nummer 1. (In Dutch)

\section{Case Enschede}

Duijn, M., Janssen, A., \& van Buuren, A. W. (2018). Meer Grip op het Ongrijpbare: De Enschedese Gemeenteraad en De Diepe Ondergrond; Eindrapport; GovernEUR Erasmus Research en Business Support BV. en Vakgroep Bestuurskunde en Sociologie Erasmus School of Social and Behavioural Sciences, Erasmus Universiteit Rotterdam. (In Dutch)

Gemeente Enschede (2018). Raadsadviescommissie Ondergrond van de Toekomst, Advies aan de gemeenteraad, 9 februari 2018. (In Dutch) 